\title{
Surfaces
}

Herman Melville, Correspondence: The Writings of Herman Melville, Vol. 14. Ed. Lynn Horth. Northwestern U. Press and The Newberry Library, Evanston and Chicago: 1993. 923 pp.

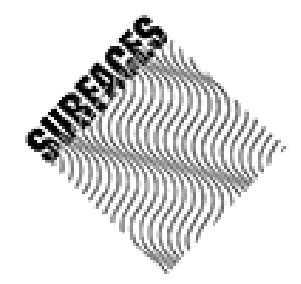

\section{François Desaulniers}

Volume 4, 1994

URI : https://id.erudit.org/iderudit/1064977ar

DOI : https://doi.org/10.7202/1064977ar

Aller au sommaire du numéro

Éditeur(s)

Les Presses de l’Université de Montréal

ISSN

1188-2492 (imprimé)

1200-5320 (numérique)

Découvrir la revue

Citer ce compte rendu

Desaulniers, F. (1994). Compte rendu de [Herman Melville, Correspondence: The Writings of Herman Melville, Vol. 14. Ed. Lynn Horth. Northwestern U.

Press and The Newberry Library, Evanston and Chicago: 1993. 923 pp.]

Surfaces, 4. https://doi.org/10.7202/1064977ar d'utilisation que vous pouvez consulter en ligne. 


\section{BOOK REVIEW \\ LYNN HORTH ED., CORRESPONDENCE: THE WRITINGS OF HERMAN MELVILLE}

\section{François Desaulniers}

Herman Melville ${ }_{2}$ Correspondence: The Writings of Herman Melville, Vol. 14. Ed. Lynn Horth. Northwestern U. Press and The Newberry Library, Evanston and Chicago: 1993. 923 pp.

Northwestern-Newberry does it again! They have produced yet another landmark edition in the series entitled "The Writings of Herman Melville." Volume fourteen of a fifteen-volume series, Melville's "Correspondence" is a must for any Melville scholars. This book is a gold mine, providing critics with many paths from which to approach Melville's other writings. But before exploring a few of its possibilities, let us first take a quick look at its particular features and at the editing process used to establish Melville's text.

Melville's correspondence is divided into two sections: letters sent and letters received. Each section is presented chronologically, totalizing 943 annotated entries, 542 of which mention unlocated letters. Twenty-five of the letters are illustrated (photographed or monogrammed) in whole or in part, giving a good idea of Melville's extremely difficult handwriting. The two major sections are separated by a small chapter entitled "Principal Persons and Places", which contains many interesting photos, portraits, and sketches. Ever wonder what Melville's mother, Maria Gansevoort, or his children looked like? You can find out in this book (I must warn those who are into genetic criticism that, except for the fluffy beard, family resemblances are hard to establish...).

Letters in each section are preceded by a headnote, which provides "relevant biographical and historical background." These short introductory texts are concise and to-the-point, summarily explaining any textual references or allusions, along with Melville's own relation to the addressee. They are a valuable aid to

most readers, even giving details of the document's physical aspects such as size and type of paper, specifications of print and signature.... 
A "textual report" is found at the foot of each entry, with information on the letter's place of residence, and the date of its first publication. Extra-textual markings and textual notes indicate the nature of any changes made by the editors (such as barred or altered words, evidently misspelled or miswritten words...).

Several chapters by the editors follow the two sections of Melville's correspondence. The first is entitled "Historical Note". This chapter gives a detailed biography of the letters themselves, retracing their history and providing relevant information on anyone who came into the slightest contact with them. We can also read the tales of the lost correspondence, those letters which mysteriously sped to their deaths on errands of life. Furthermore, the editors quote letters in Melville's work (such as in Pierre), cite criticism of letters published, and provide additional details on Melville's relation to correspondants and his attitude towards letter-writing.

"Note On The Text" is a chapter in which the editors discuss their policies. As they put it: "The critical texts in this volume...attempt to present Melville's intentions in the act of writing...." In general terms they explain critical changes to unclear or elided words (for example), the addition of omitted words, their reading of Melville's hand.... Changes are always made for the most likely possibility, following the laws of common usage, and Melville's own idiosycratic usage is preserved when established by comparative studies. As I mentioned earlier, all textual changes or uncertainties are indicated in the notes following each individual letter. These changes make reading much less tedious and the text much more comprehensive. Even the most suspicious of Melville scholars have little reason and less time for them not to place their faith in the editors' modifications. This book is clearly the result of hard and serious editing work, and I have not come upon one change which I deemed doubtful or unjustified.

The remaining chapters by the editors are odds and ends which contribute to make this book, true to the others in the same series, of an incomparable quality. "Conjectural and Alternative Readings" provides a copy of unreadable words in Melville's own hand, mentions the texts in which they are found, and gives any possible (though less likely) alternatives. Another chapter is entirely devoted to Melville's handwriting. Others cite a possible Melville letter, two letters concerning Melville.... Near the end of the book we find a calendar listing all letters, written and received, with date written (or, when unavailable, a probable date is given with date of first publication). This calendar also has brackets in the left margin which discreetly link letters with replies. The crowning feature of this work is an index of people, themes, and places found in Melville's letters, such as "truth", "insanity", and "Plato", for example.

Now to return to my first question: why should anyone be interested in Melville's letters? As I already mentioned, these letters "provide critics with many paths from which to approach Melville's other writings." They are not 
just historical curiosities or mere biographical artefacts. They can be linked to other texts presented under (above) Melville's signature, and are a valuable part of a series of works which include Melville's "fictions". I can only conclude by providing a few examples with a short paragraph on how they might help critics in their readings. Of course these are only a few of innumerable possibilities. The advantage readers want to take from these letters depends greatly on the depth and nature of their particular studies...

Would that a man could do something \& then say -- It is finished. -- not that one thing only, but all others -- that he has reached his uttermost, \& can never exceed it. But live \& push -- 'tho we put one leg forward ten miles -- it is no reason the other must lag behind -- no that must again distance the other -- \& so we go till we get the cramp \& die. (To Evert A. Duyckinck; 5 april, 1849).

This quote may be read -- not as a suggestion to go jumping around with both legs tied together -- but as an allegory of the ethics of reading and of criticism itself. Criticism as allegory is a process which never comes to an end, an interminable quest in search of the text which acts out the story of its own misreading. In other words, if one is discussing how no criticism can possibly live up to the text, due in part to the necessary and inevitable injustices which spring from the application of theory, this quote may come in as a fine exemplum. Reading as science, one form of radical hermeneutics, implies that both legs have crossed the finish line in a just reading which states the truth of the text -- its meaning -- once and for all. A critical reading of The Confidence Man, for example, as a call to resist the totalitarianism of truth in favor of a justice of indeterminacy, might profit from Melville's extended metaphor quoted here.

Another example: "The truth is that we are all sons, grand-sons, nephews or great-nephews of those who go before us. No one is his own sire." (To Evert A. Duyckinck; 3 March, 1849). This quote goes in the same direction as the previous, and can be used in a discussion of allegory per se. Allegory being the production of text in the process of reading (previous texts), this example highlights the heterogeneity of all acts of creation, especially critical writing. Contrary to Kant's idea of an autonomous subject who attains justice through disinterested judgement, criticism implies a necessary and inescapable relation with those who came before, a relation with the texts that precede our own and allow us to produce. No critics are their own sires. The heteronomy of reading renders impartial or objective criticism impossible. Autonomous critics, if they wish to assume their autonomy, must refrain from the act of reading altogether in order to escape the rhetorical effects of language which make their judgements partial. Critics are part of their own process, along with the texts they study, and no matter how strongly they wish to deny their dependance on the language of others, this denial remains a denegation of those who came before, a rejection of the heritage which they have received, for better and for worse. 
One more:

This is a long letter, but you are not at all bound to answer it. Possibly, if you do answer it, and direct it to Herman Melville, you will missend it -- for the very fingers that now guide this pen are not precisely the same that just took it up and and put it on this paper. Lord, when shall we be done changing? (To Nathaniel Hawthorne; [17?] November 1851).

One could write a whole essay on this quote alone. Melville's notion of the subject, here at least, is fatal for the hermeneutic reader. Of course hermeneutics must not be brushed aside as useless or inconsequent -- on the contrary, the process of reading always tends towards a certain circularity. But if a particular subject starts out on a quest in search of the text, what to say about the point of arrival? At the circle's end lies a different subject, one who's thesis or premise remains just as arbitrary (being imposed by a different subject, the premise is an exterior condition) as it was in the beginning -- it is, finally, missent. Could we link this quote to a reading of "Bartleby, the Scrivener", who himself worked in the Dead Letter Department? I certainly would (and have...).

Readers may take my examples for what they will, but I simply wish to show the value of Melville's correspondence to literary criticism. As I mentioned earlier, the possibilities are endless, and the index found in the Northwestern-Newberry edition will save time and effort for hard-pressed readers who can't go through all the letters. Besides the practical value of this book, Melville's letters are fun reading, written in Melville's incomparable (though often compared) style. Moreover, this book is reasonably priced in the softback version, an important factor for most students. I recommend it most highly.

\section{François Desaulniers}

\section{Dépt. de Littérature Comparée}

\section{Université de Montréal}

